\title{
Protokoły z posiedzeń organizacji karaimskich w II Rzeczypospolitej (1924-1928)
}

\author{
Rafał Witkowski \\ Uniwersytet im. Adama Mickiewicza, Wydział Historyczny \\ Instytut Historii
}

\begin{abstract}
The Minutes of the Karaite Organizations Based in the Republic of Poland (1924-1928)
\end{abstract}

\begin{abstract}
Summary: The minutes of the various social and religious Karaite organizations shed light on the most important questions of their existence in the Republic of Poland after WW I, when the Karaites had to reestablish their legal, religious and social position.
\end{abstract}

Keywords: Karaite organizations, Vilnius, Trakai, Lutsk, hachan, hazzan, social life, religious life.

Biblioteka im. Wróblewskich Litewskiej Akademii Nauk przechowuje zbiór protokołów i sprawozdań z posiedzeń organizacji karaimskich, głównie religijnych, które w okresie dwudziestolecia międzywojennego działały na obszarze Rzeczypospolitej. Tego rodzaju teksty można odnaleźć w kilkunastu teczkach, które nie tworzą jednej, zwartej kolekcji. Wymowa tych dokumentów, tak dla poznania prawnych warunków funkcjonowania Karaimów, jaki i codziennej egzystencji jako wspólnoty religijnej i mniejszości społecznej, jest trudna do przecenienia. Wydaje się zatem, że przygotowania zwartej edycji tego rodzaju dokumentów jest jednym z najpilniejszych zadań dla badaczy zainteresowanych przeszłością Karaimów. 
Niniejsza edycja zawiera wybór kilku tekstów z okresu poprzedzającego wybór Seraji Szapszała oraz okoliczności objęcia przez niego godności hachana karaimskiego. Zastosowana uwspółcześnioną ortografię (np. zamiast protokuł jest protokól, zamiast organizacyj jest organizacji, zamiast Zacharjasz jest Zachariasz), zachowując jednak styl i kompozycję zdań. W nawiasach kwadratowych podano odpowiednio numery stron albo kart.

[r]

\section{Protokół}

Konferencji przedstawicieli organizacji oraz gmin karaimskich w Wilnie, Trokach, Łucku oraz Haliczu, jaka się odbyla w Wilnie dnia 30 listopada 1924 rok $^{1}$

Byli obecni p. p.

Od Duchownego Zarządu Karaimskiego w Trokach:

Firkowicz Szymon

Zajączkowski Achiezer

Od Zarządu Wileńskiego Stowarzyszenia Karaimów:

Kobecki Emanuel

Zajączkowski Izaak

Rojecki Ananiasz

Od wileńskiego społeczeństwa:

Aronowicz Emanuel

Jutkiewicz Eliasz

Jutkiewicz Józef

Kalfa Eliasz

Kobecki Aleksander

Kobecki Eliasz

Kozyrowicz Józef

Łabanos Józef

Od trockiego społeczeństwa:

Abkowicz Rafał

Nowicki Dawid

Nowicki Józef

Zajączkowski Józef

Od halickiej gminy wyznaniowej:

Dr Nowachowicz Zachariasz

1 LVMAB F 301-448, fol. 1 r, 2 r, 3 r, 4 r, 5 r, 6 r, 7 r, 8 r, 9 r, 10 r, 11 r, 12 r, 13 r; odpis przygotował Zarząd Wileńskiego Stowarzyszenia Karaimów dnia 24 stycznia 1925 r. 
Od Stowarzyszenia wyznaniowego Karaimów w Łucku:

Prezydium Zarządu Wileńskiego stowarzyszenia Karaimów.

Zagaił konferencję o godzinie $11 \mathrm{~m}$. 15 rano prezes Wileńskiego Stowarzyszenia Karaimów p. Emanuel Kobecki, oświadczając, iż konferencję Zarząd Stowarzyszenia zwołał z zezwolenia Pana Komisarza Rządu na m. Wilno z dnia 25 listopada 1924 r. L. 5136 (V) 23. Następnie prezes Zarządu Stowarzyszenia powołał uczestników konferencji do wyboru przewodniczącego oraz sekretarza. Jednogłośnie wybrano [2] na przewodniczącego dra Zachariasza Nowachowicza z Halicza, na sekretarza zaś p. Ananiasza Rojeckiego z Wilna.

Po objęciu przewodnictwa dr Z. Nowachowicz oświadczył, iż zadaniem konferencji będzie rozpatrzenie sprawy projektów „Tymczasowych Przepisów o stosunku Rządu do Związku Religijnego Karaimskiego” oraz „Statutu karaimskiej gminy wyznaniowej”, jakie to projekty Zarząd Wileńskiego Stowarzyszenia Karaimów przedłożył władzom dnia 6 czerwca 1923 r. i w dniu 15 listopada 1924 r. otrzymał z powrotem dla zmian i uzupełnień w związku z uwagami pana wojewody stanisławowskiego ${ }^{2}$.

Przewodniczący udzielił głosu prezesowi Wileńskiego Stowarzyszenia Karaimów, p. E. Kobieckiemu, który odczytał referat, uwidoczniając w nim stosunek b. Rządu Rosyjskiego do Karaimów oraz genezę i przebieg sprawy projektów „Tymczasowych Przepisów o stosunku Rządu do Związku Religijnego Karaimskiego” i „Statutu karaimskiej gminy wyznaniowej” od połowy r. 1921 aż do chwili otrzymania przez Prezesa Zarządu Wileńskiego Stowarzyszenia Karaimów w tej sprawie pisma Delegata Rządu w Wilnie z dnia 13 listopada 1924 r. L. 2425/I, do którego załączono uwagi pana wojewody stanisławowskiego do „Tymczasowych Przepisów” i „Statutu”.

Przewodniczący wystąpił z propozycją przeprowadzenia dyskusji nad referatem p. E. Kobeckiego. Głosu nikt z obecnych nie brał, natomiast p. Izaak Zajączkowski zgłosił wniosek następujący: „Konferencja referat p. E. Kobeckiego przyjmuje do wiadomości oraz wyraża mu podziękowanie za sumienne i szczegółowe opracowanie referatu”. Konferencja wniosek ten uchwaliła jednogłośnie.

Zabrał ponownie głos p. Emanuel Kobecki i oświadczył, iż do Zarządu Wileńskiego Stowarzyszenia Karaimów wpłynęło od Zarządu Stowarzyszenia Wyznaniowego Karaimów w Łucku upoważnianie z dnia 26 listopada 1924 r. L. 9 do zastępowania gminy karaimskiej w Łucku w sprawach, będących na porządku dziennym konferencji. W równej mierze dr Zachariasz Nowachowicz przedłożył upoważnienie zastępcze gminy halickiej z dnia 23 listopada 1924 r. № 41/24 .

W dalszym ciągu p. Emanuel Kobecki ogłosił wniosek Zarządu Wileńskiego Stowarzyszenia Karaimów treści następującej:

2 Wojewodą stanisławowskim był wówczas Edmund Jurystowski (1873-1956). 
[3] „Jak widać z referatu prezesa Zarządu, projekty „Tymczasowych Przepisów o stosunku Rządu do Związku Religijnego Karaimskiego i o zasadach zarządzania sprawami duchownemi karaimów” oraz „Statutu karaimskiej gminy wyznaniowej” rozpatrywano na walnych zgromadzeniach wiernych w Wilnie, Trokach, Łucku i Haliczu, które miały charakter konstytucyjny. Zebranie niniejsze, jaką by ono nie posiadało wagę gatunkową, nie może według zdania Zarządu Stowarzyszenia być uznane za prawomocne do zmiany zasad podstawowych projektów, które Zarząd Stowarzyszenia skodyfikował i przedłożył władzom administracyjnym dnia 6 czerwca roku ubiegłego, jako wyraz zgodnej opinii ogółu karaimów. Niniejsze zebranie jest moralnie uprawnione do poczynienia takich tylko zmian, które nie podważają podstaw projektów o organizacji władz duchownych lub gminnych, a jedynie udoskonalają aparat tych władz lub zadość czynią interesom Państwa. Wychodząc z tego założenia, Zarząd Stowarzyszenia składa wniosek następujący:

1) Całości projektów „Tymczasowych Przepisów o stosunku Rządu do Związku Religijnego Karaimskiego i o zasadach zarządzania sprawami duchownymi karaimów” oraz „Statutu karaimskiej gminy wyznaniowej”, przedłożonych przez Zarząd Stowarzyszenia władzom dnia 6 czerwca 1923 r. konferencja nie rozpatrzy;

2) Konferencja rozważy uwagi wojewody stanisławowskiego do „Tymczasowych Przepisów” oraz „Statutu”. Co do uwag, podważających przyjęte przez ogół Karaimów podstawy ustroju władz duchownych i gminnych konferencja ograniczy się do umotywowania stanowisk ogółu Karaimów oraz krytyki argumentacji wojewody, uzasadniającej proponowane zmiany. Co do uwag, które nie podważają podstaw ustroju władz duchownych lub gminnych, a mają na celu udoskonalenie aparaty tych władz oraz interes Państwa, konferencja poważnie decydujące uchwały, należycie umotywowane;

3) Konferencja ustali i uzgodni stanowiska poszczególnych gmin co do możności uzyskania „Statutu karaimskiej gminy wyznaniowej”, nie czekając zatwierdzenia przez Rząd „Tymczasowych Przepisów”;

4) Konferencja wezwie Duchowny Zarząd Karaimski w Trokach do przychylnego potraktowania tak całości projektów „Tymczasowych Przepisów” oraz Statutu”, jak i poszczególnych postanowień [4] podstawowych, przyjętych przez gminy karaimskie bądź jednomyślnie, bądź większością trzech gmin i będących wobec tego wyrazem opinii ogółu Karaimów.

Ponadto biorąc pod uwagę, iż zaproszenia na niniejszą konferencję miały charakter osobisty co do Trok i Wilna bez uwzględnienia liczebności wiernych, aby zapobiec majoryzacji jednych gmin nad drugimi, Zarząd Stowarzyszenia stawi również wniosek następujący:

1) W celu wszechstronnego wyświetlenia podlegających rozpatrzeniu kwestii w dyskusji biorą udział wszyscy bez wyjątku uczestnicy konferencji.

2) W sprawach formalnych głos decydujący należy do każdego uczestnika konferencji i

3) Decyzje in meritum spraw będą powzięte przez gminy.” 
W dyskusji wniosek Zarządu Stowarzyszenia uzasadniał wiceprezes Zarządu. p. Izaak Zajączkowski, wyrażając pogląd, iż „Tymczasowe Przepisy” oraz „Statut” były już rozpatrywane na walnych zgromadzeniach w Wilnie, Trokach, Łucku i Haliczu, jakie to zgromadzenia miały charakter konstytucyjny. Obecnie, zdaniem mówcy, nie możemy zmieniać zasad, zaakceptowanych przez gminy projektów, jedynie uprawnieni jesteśmy do zmian, mających charakter formalny. Dr Z. Nowachowicz nie zgodził się z przedmówcą i oświadczył, iż projekty przepisów można reasumować na walnych zgromadzeniach gminnych, nie powinny jednak one być w kolizji z ogólnym prawem państwowym. Uwagi pana wojewody stanisławowskiego musimy rozpatrzeć i swą opinię poddać rozpatrzeniu walnych zgromadzeń gminnych po uprzednim uzgodnieniu z Urzędem p. Delegata Rządu w Wilnie. Co do wniosku Zarządu Stowarzyszenia mówca proponuje ograniczyć się do końcowych wstępów. P. Izaak Zajączkowski zaproponował dyskusję nad wnioskiem przerwać, przechodząc do rozpatrzenia sprawy in meritum. P. A. Rojecki, nawiązując do oświadczenia dra Z. Nowachowicza, zaznaczył co następuje: 1) statuty są zgodne z Ustawą Konstytucyjną z dnia 17/III - 1921 r., tj. osnute są na ogólnym prawie państwowym i 2) obowiązujące w Małopolsce przepisy są w sprzeczności a przerwami, obowiązującymi w województwach wschodnich. Wpłynął wniosek p. Izaaka Zajączkowskiego „Wstrzymać dyskusję nad wnioskiem Zarządu Stowarzyszenia i rozpatrzyć go po rozpatrzeniu uwag pana wojewody stanisławowskiego”. P. Eliasz Jutkiewicz [5] zaznaczył, iż jego zdaniem, mają prawo głosować jedynie trzy osoby: dr Z. Nowachowicz w charakterze zastępcy gminy halickiej, przedstawiciel Zarządu Duchownego pan S. Firkowicz oraz jeden z członków Zarządu Wileńskiego Stowarzyszenia Karaimów w charakterze zastępcy gminy łuckiej, gminy zaś wileńską i trocką pozbawione są formalnego przedstawicielstwa na konferencji. Pan A. Rojecki oświadczył, że na konferencji są obecne literalnie wszystkie te osoby, które biorą czynny udział w karaimskim życiu społecznym w Wilnie i w Trokach, faktycznie więc wyrażają one opinię większości członków gmin wileńskiej i trockiej. Jeżeli nawet konferencja z punktu widzenia formalnego i nie jest organem prawomocnym, to faktycznie jest ona uprawniona do powzięcia decyzji ostatecznych. Zabrał ponownie głos pan Izaak Zajączkowski, który, cofając swe poprzednie wnioski, zaznaczył, iż: 1) należałoby powrócić do wniosku Zarządu Wileńskiego Stowarzyszenia Karaimów i 2) że formalnie na Konferencji przedstawione są wszystkie gminy: halicka w osobie dra Z. Nowachowicza, łucka w osobie p. Emanuela Kobeckiego, wileńska w osobie jednego z członków Zarządu Wileńskiego Stowarzyszenia Karaimów, oraz trocka w osobie członka Duchownego Zarządu Karaimskiego, pana Sz. Firkowicza. Pan Eliasz Jutkiewicz oświadczył w swym imieniu oraz w imieniu p. p. Eliasza Kobeckiego, Józefa Łabanowa i Józefa Jutkiewicza protest przeciw uprawnieniom Zarządu Wileńskiego Stowarzyszenia Karaimów do zastępstwa gminy wileńskiej. Prezes Zarządu Stowarzyszenia, pan E. Kobecki, wobec tego oświadczył, iż rzeczywiście deklaracją z dnia 2 lutego r.b. Zarząd Stowarzyszenia zrezygnował z funkcji organu 
reprezentacyjnego i wykonawczego gminy wileńskiej „Tymczasowych Przepisów” oraz „Statutu”, albowiem gmina jak dotychczas niezdolna była wyłonić taki aparat wykonawczy, który byłby zdolnym do prowadzenia sprawy tej miary. Ostatnio na zgromadzeniu gminnym w dniu 1 listopada r.b. czynione były próby stworzenia wspólnego zarządu dla gminy i Stowarzyszenia, lecz ani jeden z pracowników umysłowych nie zgłosił swej kandydatury.

Wobec rozbieżności zdań co do uprawnień Konferencji, pan Ananiasz Rojecki wystąpił z następującym wnioskiem: 1) uznać, iż Konferencję zwołano w celu uzgodnienia stanowiska poszczególnych [6] gmin do projektu Statutu gminy wyznaniowej oraz rozpatrzenia uwag p. Wojewody Stanisławowskiego i 2) po powrocie delegatów do gmin, zwołać niezwłocznie walne zgromadzenia parafian, u których uzyskać akceptację decyzji Konferencji, oraz 3) po rozpatrzeniu spraw na walnych zgromadzeniach przekazać sprawę dla definitywnego załatwienia Zarządowi Wileńskiego Stowarzyszenia Karaimów, ewentualnie specjalnej Komisji, która byłaby wybrana na Konferencji.

Pan Emanuel Kobiecki oświadczył, iż konferencja nie będzie rozpatrywała ponownie zasadniczych, artykułów „Tymczasowych Przepisów” oraz „Statutu”. Pan Izaak Zajączkowski proponuje uznać, iż na konferencji biorą udział nie przedstawiciele gmin, a osoby poszczególne, zaś uchwały konferencji, uzgodnione z Duchownym Zarządem Karaimskim w Trokach, będą skierowane do Urzędu Delegata Rządu w Wilnie. Przewodniczący zreasumował zdania, wypowiedziane podczas dyskusji. Zgodnie z resumé przewodniczącego pan A. Rojecki zgłosił następujący wniosek kompromisowy: „Czyniąc zadość pismu Delegata Rządu w Wilnie z dnia 13/XI - 1924 r. L. 2425/I, p. p. Emanuel Kobecki, Izaak Zajączkowski oraz Ananiasz Rojecki, w imieniu Zarządu Wileńskiego Stowarzyszenia Karaimów oraz zastępczo w imieniu Zarządu Stowarzyszenia Wyznaniowego Karaimów w Łucku przy udziale przedstawicieli Duchownego Zarządu Karaimskiego w Trokach w osobach pana Szymona Firkowicza oraz pana Achiezera Zajączkowskiego, delegata gminy Halickiej dra Zachariasza Nowachowicza, na wspólnej konferencji z p.p. od społeczeństwa wileńskiego: Emanuelem Aronowiczem, Eliaszem Jutkiewiczem, Józefem Jutkiewiczem, Eliaszem Kalfą, Aleksandrem Kobeckim, Eliaszem Kobeckim, Józefem Kozyrowiczem i Józefem Łabanosem, oraz od społeczeństwa trockiego - Rafałem Abkowiczem, Dawidem Nowickim, Józefem Nowickim i Józefem Zajączkowskim, zaproszonymi przez Zarząd Wileńskiego Stowarzyszenia Karaimów, w sprawie projektu modyfikacji niektórych artykułów „Tymczasowych Przepisów” oraz „Statutu”, zaprojektowanych przez pana wojewodę stanisławowskiego w piśmie z dnia 27 września 1924 r. L. 5096/V, powzięli następujące uchwały.

Powyższy wniosek, jako przejście do porządku dziennego wnioskiem Zarządu Stowarzyszenia, poddany przez przewodniczącego głosowaniu, został przyjęty przez wszystkich obecnych z wyjątkiem p. Eliasza Jutkiewicza, który się wstrzymał od głosowania. [7] 
Następnie Konferencja przystąpiła do rozpatrywania meritum sprawy.

Na wniosek Zarządu Stowarzyszenia Konferencja jednogłośnie uchwaliła sprawy rozpatrzeć w takim porządku: 1) uwagi do Statutu karaimskiej gminy wyznaniowej oraz samą sprawę wprowadzenia w życie Statutu i 2) uwagi do „Tymczasowych Przepisów”.

Po rozpatrzeniu uwag P. Wojewody Stanisławowskiego do „Statutu”, Konferencja jednomyślnie uchwaliła:

1) W artykule 20 „Statutu” dodać uwagę 2-ga:

„Protesty przeciw postępowaniu wyborów członków Zarządu rozpatruje władza administracyjna 1 instancji”.

2) Do zasadniczego artykułu 20 dodać ustęp:

„Oprócz członków wybieranych w skład Zarządu wschodzi z urzędu z prawem głosu decydującego miejscowy parafialny proboszcz karaimski (Hazzan) lub w zastępstwie jego wikary”.

3) Do artykułu 21 dodać:

„Prezes Zarządu, jako przełożony Gminy, składa przyrzeczenie na ręce zastępcy władzy administracyjnej I instancji”.

Ponadto w celu ustanowienia jednolitego brzmienia Statutu dla wszystkich gmin karaimskich oraz możliwości wprowadzenia go w życie, nie czekając „Tymczasowych Przepisów”, sprawa zatwierdzenia których jest więcej skomplikowaną, Konferencja jednogłośnie powzięła następujące uchwały:

1) W art. 16: „przyjęcia do religii karaimskiej osób innego wyznania”, zaś w art. 17 pozycję szóstą, przewidującą, iż na walnych zgromadzeniach rozpatruje się sprawy przyjęcia do religii karaimskiej osób innego wyznania skreślić. Uchwałę tę przyjęto wszystkimi głosami, przy wstrzymującym się drze Z. Nowachowiczu, który zastrzegł gminie halickiej możność zająć to lub inne stanowisko, i

2) skreślić na razie ze Statutu powołania się na „Tymczasowe Przepisy”, a mianowicie:

- uwagę do art. $16 \mathrm{i}$

- uwagę tę do art. 17, z tym, iż uwaga druga będzie sygnowana, jako pierwsza. [8]

Następnie na wniosek pana Eliasza Jutkiewicza konferencja powzięła jednomyślnie uchwałę „Prosić Zarząd Wileńskiego Stowarzyszenia Karaimów, aby spowodował jak najrychlejsze wprowadzenie w życie „Statutu Karaimskiej Gminy Wyznaniowej”, uzgodnionego przez wszystkie Gminy w Polsce oraz z uwagami pana wojewody stanisławowskiego".

Z kolei konferencja przeszła do uwag pana wojewody stanisławowskiego do projektu „Tymczasowych Przepisów o stosunku Rządu do Związku Religijnego Karaimskiego”. 
Zabrał w tej materii głos prezes Zarządu Wileńskiego Stowarzyszenia Karaimów pan E. Kobecki i wypowiedział następującą opinię Zarządu Stowarzyszenia o uwagach pana wojewody stanisławowskiego: „Propozycje pana wojewody nacechowane na dążność do zbytniej reglamentacji Związku Religijnego Karaimskiego. Rzecz charakterystyczna, iż ustawa rosyjska o zarządzaniu sprawami duchownymi Karaimów z lat pięćdziesiątych XIX wieku, tj. z czasów bezwzględnych rządów absolutystycznych ingerencję władzy administracyjnej przewidywała tylko w dwóch wypadkach: 1) odwołania osób zainteresowanych od decyzji hachama i 2) niezgodności tych decyzji z ustawami oraz zarządzeniami władzy wyższej. Po zatem czynności hachama oraz Zarządu Duchownego nie podlegały specjalnej reglamentacji lub kontroli. Ta drobiazgowa opieka administracyjna, która pan wojewoda stanisławowski proponuje roztoczyć nad wewnętrznym życiem Związku nie harmonizuje z Ustawą Konstytucyjną z dn. 7 marca 1921 roku, która mniejszościom językowym oraz wyznaniowym gwarantuje używanie swego języka oraz samodzielnie prowadzenie swych spraw wewnętrznych (art. 110 i 113)”. Takie jest, dodał pan E. Kobecki, stanowisko Zarządu Stowarzyszenia do uwag z punktu widzenia politycznego. Oprócz tego przy rozpatrywaniu uwag poszczególnych Zarząd Stowarzyszenia uwidoczni swe stanowisko również ze strony technicznej.

Konferencja jednomyślnie przyjęła do wiadomości oświadczenie Zarządu Stowarzyszenia oraz przeszła do rozpatrzenia poszczególnych uwag.

1) W uwagach do art. 3 i 7 zada się zatwierdzanie wszelkich uchwał konsystorza oraz zjazdów kleru i świeckich przez Rząd oraz nominacje sekretarza konsystorza przez władzę administracyjną drugiej instancji. [9]

Po wysyłaniu opinii Zarządu:

a) że zatwierdzania wszystkich uchwał konsystorza przez Rząd spowodowałoby znaczną zwłokę w toku spraw oraz utrudniałoby Wydział wyznań Urzędu Delegata Rządu w Wilnie, posiadający jedną siłą wykonawczą.

b) że interes państwa pod tym względem może być zagwarantowany wprowadzeniem klauzuli, iż uchwały konsystorza winne być zgodnie z ogólnymi ustawami oraz zarządzeniami władzy wyższej zaś nie odpowiadające tym warunkom uchwały mogą być w drodze nadzoru uchylone przez władzę administracyjną drugiej instancji.

c) że zjazdy kleru i świeckich będą zwoływane dla rozpatrywania nie zaś decydowania spraw większej wagi, że sprawy dogmatycznie nie obchodzą władze administracyjne w innych zaś sprawach zjazdy będą wypowiadały pewne postulaty, które wprowadzi w czyn konsystorz z zachowaniem przepisów prawa ogólnego, to jest w odpowiednich wypadkach po zatwierdzeniu przez Rząd, z jakich to punktów widzenia nie należy uchwały zjazdów o kleru i świeckich przedkładać na zatwierdzenie Rządu i

d) że o ile to Rządowi bardzo zależy, postulat zatwierdzania przez władzę administracyjną drugiej instancji nominacji sekretarza konsystorza może być przyjęty. 
Konferencja jednogłośnie uchwaliła zaakceptować przedłożone przez Zarząd Stowarzyszenia brzmienie ostatniego ustępu art. 3:

„Konsystorz w swych uchwałach winien ściśle przestrzegać ogólne ustawy państwowe oraz zarządzania władzy wyższej. Uchwały nieodpowiadające tym warunkom Delegat Rządu w Wilnie ma prawo w drodze nadzoru uchylić. Od tych zarządzeń konsystorzowi przysługuje prawo odwołania do Ministra W. R. i O. P. „Akta Konsystorza prowadzi Sekretarz, którego wyznacza konsystorz spośród osób wyznania karaimskiego posiadających obywatelstwo polskie, a zatwierdza Delegat Rządu w Wilnie”.

2) Uwagi do art. 6 mają swym przedmiotem działalność hazzanów jako urzędników stanu cywilnego.

Uwzględniając opinię Zarządu Stowarzyszenia, iż uwagi te mają wyraz całkowity w art. 18 „Tymczasowych Przepisów”, Konferencja jednogłośnie uchwaliła artykuł 6 pozostawić w brzmieniu do tych czasów. W każdym bądź razie konferencja uchwaliła zaznaczyć, iż zastrzeżenie [Io] co do prowadzenia ksiąg stanu cywilnego przez hazzanów - o ile Urząd Wojewódzki inaczej nie zarządzi - jest dla konferencji nie do przyjęcia.

3) W uwagach do art. 9 wojewoda stanisławowski gorąco popiera zapatrywanie karaimów w Haliczu o konieczności dożywotniego wyboru wszelkich osób duchownych, w razie ostatecznym proponuje: 1) przedłużyć odpowiednio kadencję urzędowania hachama jako naczelnego duchownego i 2) hazzanów wybierać na trzyletni okres próbny z prawem po upływie tego terminu ustabilizowania lub zwolnienia.

Po wysłuchaniu opinii Zarządu Stowarzyszenia:

a) że w diecezji trockiej, egzystującej lat 70, w ciągu lat 40-tu przy staroświeckim trybie życia karaimów nie odczuwano braku odpowiednich kandydatów na stanowisko hachama i hazzanów, którzy urzędowali dożywotnio, ciesząc się uznaniem i poważaniem wiernych, w ostatnich jednak 30-tu latach z różnych przyczyn odpowiedni pod względem fachowym i moralnym kandydaci o tyle niechętnie się oddawali zawodowi duchownemu, iż stanowisko hachama nie było obsadzone w latach 1898-1902, zaś od roku 1910 jest wakujące; co się tyczy hazzanów, to były wypadki zwolnienia ich z urzędów przez władze administracyjne tak zaborcze, jak i polskie;

b) że wobec tego gminy karaimskie z byłego zaboru rosyjskiego uważają, iż byłoby najwłaściwszym nie zaangażowywać się dożywotnim wyborem osób duchownych;

c) że co do uwagi pana wojewody, iż mianowanie dożywotnie podniesie powagę osób duchownych, należy zaznaczyć, iż najwyższych dostojników państwowych - Prezydentów Republik - wybiera się co najwyżej na lat 7, jak w Polsce lub we Francji, a w Stanach Zjednoczonych Ameryki Północnej nawet na 4 lata, co w niczym jednak nie poniża powagi Prezydenta; 
d) że aluzje pana wojewody co do roznamiętnienia publicznego oraz możliwych korupcji przy częstych wyborach osób duchownych w istocie rzeczy są negacją samej zasady wszelkich wyborów.

Konferencja przystąpiła do dyskusji nad uwagami pana wojewody. P. p. Eliasz Jutkiewicz, Ananiasz Rojecki oraz Achiezer [II] Zajączkowski uzasadniali konieczność terminowości wyborów osób duchownych, Józef Zajączkowski z Trok uzasadniał konieczność wyborów bezterminowych, proponując zarazem, aby był zachowany postulat ustawy rosyjskiej, iż po upływie trzech lat wolno nie mniej, niż 2/3 parafjan prosić o wybór nowego hazzana. Pan Emanuel Kobecki oświadcza, iż należy zachować terminowość wyborów, albowiem za tym wypowiedziały się w swoim czasie trzy gminy: wileńska, trocka i łucka, Zarząd zaś Stowarzyszenia nie posiada dowodów, iż opinia tych gmin pod tym względem zmieniła się.

Po wyczerpaniu dyskusji Przewodniczący na żądanie grupy uczestników konferencji zarządził imienne głosowanie, wyniki którego były następujące: za terminowością wyborów osób duchownych wypowiedziało się 12 osób: p.p. Emanuel Aronowicz, Izaak Zajączkowski, Ananiasz Rojecki, Achiezer Zajączkowski, Eliasz Kalfa, Józef Kozyrowicz, Eliasz Jutkiewicz, Emanuel Kobecki, Józef Łabanos, Józef Jutkiewicz, Aleksander Kobecki i Rafał Abkowicz; za bezterminowością wyborów wypowiedziała się 1 osoba - pan Józef Nowicki; wstrzymały się od głosowania 4 osoby: dr Zachariasz Nowachowicz, Szymon Firkowicz, Józef Zajączkowski i Dawid Nowicki.

Pan Ananiasz Rojecki postawił pytanie, jakie jest w tej kwestii stanowisko członka Zarządu Duchownego pana Sz. Firkowicza. Przewodniczący, pytanie to ze względów formalnych zdjął z porządku dziennego.

4) w uwagach do art. 10 stawia się warunek, że czynne prawo wyborcze winno być uzależnione od niszczenia przez wiernych świadczeń za rok administracyjny.

Wywiązała się dyskusja tak nad uwagą pana wojewody, jak i nad kwestią uprawnień kobiet.

Ze strony Zarządu Duchownego p. p. Szymon Firkowicz oraz Achiezer Zajączkowski wypowiedzieli zdanie, iż, nie mając nic przeciwko temu, aby kobiety brały czynny udział w sprawach gminy wyznaniowej, nie uznają natomiast za możliwy ze wzglądów kanonicznych udział kobiet w wyborach karaimskich osób duchownych. P. p. Rafał Abkowicz oraz Józef Zajączkowski również z tychże względów wypowiedzieli się przeciwko prawu kobiet do wyborów [12] osób duchownych. P. p. Eliasz Jutkiewicz, Izaak Zajączkowski oraz Emanuel Kobecki uzasadniali z punktu widzenia ogólnego prawo kobiet do wyborów osób duchownych, przy czym p. Emanuel Kobecki oświadczył, iż o ile zwolennicy pozbawienia kobiet prawa wyboru osób duchownych uzasadniają to powołaniem się na ogólne prawo dogmatyczne lub kanoniczne, nie będzie to miało żadnego znaczenia; o ile uzasadnia 
powołaniem się na konkretne przepisy prawa dogmatycznego lub kanonicznego, to te można interpretować w tym lub innym kierunku. Zapytany członek Zarządu Duchownego, pan Sz. Firkowicz, oświadczył, iż o ile to będzie koniecznym, uzasadni swój punkt widzenia powołaniem się na konkretne przepisy duchowne. Rafał Abkowicz powołał się na jeden z ustępów Pisma Świętego, jaki według jego zdania zaprzecza prawu kobiet do wyborów osób duchownych, lecz prezes Zarządu Wileńskiego Stowarzyszenia Karaimów, pan Emanuel Konecki stanowczo sprzeciwił się traktowaniu sprawy in meritum, wychodząc z tego założenia, iż Konferencja, powołana jedynie do rozpatrywania „Tymczasowych Przepisów” oraz „Statutu”, należących do dziedziny prawa administracyjnego, nie może pozytywnie się zajmować dogmatami oraz kanonami, wobec czego Przewodniczący zdjął oświadczenie pana Abkowicza z porządku dziennego. Wreszcie przewodniczący dr Z. Nowachowicz oświadczył, iż zwolennicy pozbawienia kobiet prawa wyborczego zbyt przeceniają znaczenie dogmatów oraz kanonów, które wytworzyły się kilka tysięcy lat temu przy odmiennych warunkach życiowych. Po wyczerpaniu dyskusji Przewodniczący na żądanie grupy uczestników konferencji poddał kwestię, czy kobiety mają prawo wyboru osób duchownych imiennemu głosowaniu, wyniki którego okazały się następujące: osiem osób wypowiedziało się za tym, iż kobiety to prawo posiadają - p.p. dr Zachariasz Nowachowicz, Izaak Zajączkowski, Ananiasz Rojecki, Eliasz Kalfa, Józef Kozyrowicz, Emanuel Kobecki, Józef Łabanos oraz Aleksander Kobecki; przeciw temu wypowiedziało się sześć osób - p. p. Józef Nowicki, Szymon Firkowicz, Achiezer Zajaczkowski, Józef Zajączkowski, Rafał Abkowicz oraz Dawid Nowicki; 3 osoby [13] wstrzymały się od głosu.

\section{Załącznik 3 do protokołu wolnego zgromadzenia parafian kienesy w Wil- nie dn. 2o. IX. [19]25}

Projekt opłat na potrzeby kienesy, opracowany przez gabbaja pana Józefa Łopatto z członkami komisji rewizyjnej panami P. Jutkiewiczem, J. Kozyrewiczem i E. Aronowiczem i zaakceptowany przez Walne Zgromadzenia parafii kenesy w Wilnie dn. 20. 11. [19]25.

\begin{tabular}{c|l|c|c}
$\begin{array}{c}\text { № } \\
\text { porządkowy }\end{array}$ & \multicolumn{1}{|c|}{$\begin{array}{c}\text { Komisja zapropo- } \\
\text { nowała wysokość } \\
\text { składki ustalić } \\
\text { w kwocie zł. }\end{array}$} & $\begin{array}{c}\text { Walne zgro- } \\
\text { madzenie } \\
\text { uchwaliła: }\end{array}$ \\
\hline 1 & Kobecki Eljasz & 2 & 3 \\
\hline 2 & Kobecki Emanuel & 3 & 5 \\
\hline 3 & Lopatto Józef & 3 & 3
\end{tabular}

3 LVMAB F 301-449, fol. 39 r - 39 v. 


\begin{tabular}{|c|c|c|c|}
\hline $\begin{array}{c}\text { № } \\
\text { porządkowy }\end{array}$ & Nazwisko i imię & $\begin{array}{c}\text { Komisja zapropo- } \\
\text { nowała wysokość } \\
\text { składki ustalić } \\
\text { w kwocie zł. }\end{array}$ & $\begin{array}{c}\text { Walne zgro- } \\
\text { madzenie } \\
\text { uchwaliła: }\end{array}$ \\
\hline 4 & Kobecki Aleksander & 2 & 2 \\
\hline 5 & Robaczewski Noe & 1 & \\
\hline 6 & Łobanos Józef & 1 & \\
\hline 7 & Pilecki Alfons & 2 & 2 \\
\hline 8 & Jutkiewicz Eliasz & 2 & 2 \\
\hline 9 & Kapłanowski Stanisław & 1 & \\
\hline 10 & Pilecki Achiezer & 1 & 2 \\
\hline 11 & Malecki Szymon & 1 & \\
\hline 12 & Jutkiewicz Izaak & 2 & 2 \\
\hline 13 & Pilecki Owadiusz & 1 & \\
\hline 14 & Zajączkowski Izaak & 2 & 3 \\
\hline 15 & Zajączkowski Aleksander & 1 & 1 \\
\hline 16 & Juchniewicz Szymon & 1 & \\
\hline 17 & Nowicki Szymon & 1 & 2 \\
\hline 18 & Kobecki Awenir & 1 & \\
\hline 19 & Kobecki Romuald & 1 & 3 \\
\hline 20 & Kozyrowicz Józef & 3 & 3 \\
\hline 21 & Michajłowicz Izaak & 2 & \\
\hline 22 & Szpakowski Emanuel & 1 & 1 \\
\hline 23 & Firkowicz Aleksander & 1 & \\
\hline 24 & Józef Nowicki & 3 & 3 \\
\hline 25 & Szyszman Borys & 3 & 3 \\
\hline 26 & Rojecki Johonatan & 1 & 5 \\
\hline 27 & Dubiński Eliasz & 1 & \\
\hline 28 & Dubiński Jakub & 1 & \\
\hline 29 & Łopatto Konstantyn & 1 & \\
\hline 30 & Dubiński Jehoszua & 2 & \\
\hline 31 & Aronowicz Emanuel & 2 & 2 \\
\hline 32 & Jufutewicz Arkadiusz & 1 & \\
\hline 33 & Łopatto Mojżesz & 2 & 3 \\
\hline 34 & Rojecki Izajasz & 2 & \\
\hline 35 & Dubiński Michał & 1 & \\
\hline 36 & Kalfa Eliasz & 2 & 3 \\
\hline 37 & Kobecki Józef & 1 & \\
\hline 38 & Abkowicz Aleksander & 1 & \\
\hline 39 & Szyszman Abram & 3 & \\
\hline 40 & Tynfowicz Zachariasz & 3 & 3 \\
\hline 41 & Erynczek Narły & 2 & \\
\hline
\end{tabular}




\begin{tabular}{|c|c|c|c|}
\hline $\begin{array}{c}\text { № } \\
\text { porządkowy }\end{array}$ & Nazwisko i imię & $\begin{array}{l}\text { Komisja zapropo- } \\
\text { nowała wysokość } \\
\text { składki ustalić } \\
\text { w kwocie zl. }\end{array}$ & $\begin{array}{l}\text { Walne zgro- } \\
\text { madzenie } \\
\text { uchwaliła: }\end{array}$ \\
\hline 42 & Moszatewicz (?) Róża & 1 & \\
\hline 43 & Szpakowska Anna & 1 & \\
\hline 44 & Abkowiczowa Zofia & 1 & \\
\hline 45 & Szyszmanowa Olga & 1 & \\
\hline 46 & Jutkiewiczówna Kamila & 1 & \\
\hline 47 & Pilecka-Szpakowska Elwira & & 2 \\
\hline 48 & Kobecka Zofia & & 1 \\
\hline 49 & Jutkiewicz Naum & 2 & \\
\hline 50 & Nowicki Eugeniusz & 3 & \\
\hline 51 & Kobecki Emil & 3 & \\
\hline 52 & Pilecki Szymon & 2 & \\
\hline 53 & Rojecki Ananiasz & & 1 \\
\hline 54 & Łopatto Aleksy & & 1 \\
\hline 55 & Łopatto Jerzy & & 1 \\
\hline 56 & Pilecki Leon & & 1 \\
\hline 57 & Szpakowski Adolf & & 1 \\
\hline 58 & Firkowiczowa Rachela & & 1 \\
\hline 59 & Nowicki Jakub & & 1 \\
\hline 60 & Kobecki Michał & & 1 \\
\hline 61 & Łopatto Nina & & 1 \\
\hline 62 & Szpakowska Tatiana & & 1 \\
\hline 63 & Chorczenko Aleksander & & 1 \\
\hline
\end{tabular}

Walne zgromadzenie parafian niniejszy projekt zaakceptowało dnia 20.09.1925.

\section{Protokół}

walnego zgromadzenia parafian wileńskiej karaimskiej kienessy odbytego w dniu 23 stycznia 1926 roku, w domu gminnym, na zasadzie zezwolenia pana Komisarza Rządu na m. Wilno z dnia 21 stycznia r. b., L. $2796^{4}$

Zebranie zagaił o godz. 8 m. 30 wiecz[orem] w imieniu Zarządu Stowarzyszenia Karaimów w Wilnie gabaj kienessy pan Józef Łopatto.

Na przewodniczącego jednogłośnie powołano pana Eliasza Jutkiewicza, na sekretarza zaś pana Szymona Nowickiego.

4 LVMAB F 301-449, fol. 1 r - 1 v. 
Przewodniczący oświadczył, iż w Wilnie osób uprawnionych do brania udziału w zebraniach - sto trzydzieści cztery.

Ponieważ na pierwsze zebranie wyznaczone na godzinę siódmą wieczorem nie zgłosiła się wymagana przez Statut Gminy jedna trzecia część osób uprawnionych, przeto powtórne zebranie jest ważne przy dowolnej ilości członków. Lista obecnych wykazuje 42 osoby.

Jednogłośnie został zatwierdzony następujący porządek dzienny: 1) zatwierdzenie protokołu poprzedniego zebrania, 2) wybory władz gminnych, i 3) wolne wnioski.

1) Po odczytywaniu przez pana Zajączkowskiego protokołu poprzedniego zebrania, takowy został jednomyślnie zatwierdzony z tym, iż wykonanie uchwał poprzedniego zebrania poleca się przyszłemu Zarządowi Gminy.

2) Pan Izaak Zajączkowski oznajmił zebranie z zakresem działalności zarządu gminy oraz wskazał, iż zgodnie ze statutem gminy, wybory władz gminnych odbywają się drogą tajnego głosowania. Następnie zastała przyjęta propozycja pana A. Rojeckiego o przeprowadzenie wyborów drogą podwójnego głosowania, to jest przy pierwszym głosowaniu będą wskazane pożądani kandydaci, z pośród których będą wybrane władze gminne, przy czym został zatwierdzony wniosek przewodniczącego, iż osoby, które otrzymują przy próbnym głosowaniu mniej niż pięć głosów, nie będą poddane powtórnemu głosowaniu.

Wyniki pierwszego głosowania następujące: panowie J. Łopato, J. Zajączkowski, E. Jutkiewicz, Sz. Nowicki, A. Kobecki. B. Szyszman, R. Kobecki, E. Aronowicz. J. Kozyrowicz. Z. Kobecka, N. Robaczewski otrzymali znaczną większość głosów ponad pięć głosów, inni zaś otrzymali mniej pięciu głosów.

Przy powtórnym tajnym głosowaniu wyniki następujące:

a) Do Zarzadu zostali powołani:

1) Eliasz Jutkiewicz, urzędnik bankowy, 40 głosów.

2) pan Józef Łopatto, właściciel ziemski, 31 głosów.

3) pan Awinir Kobecki, urzędnik państwowy, 28 głosów.

4) pan Szymon Nowicki, urzędnik państwowy, 27 głosów.

5) Izaak Zajączkowski, adwokat, 25 głosów. [15 v]

7) Feliks Malecki, jako duchowny kienessy, członek Zarządu z urzędu, zgodnie z par. 20 Statutu.

Wobec tego, iż pozostałe osoby otrzymali mniej połowy głosów obecnych na zebraniu, przewodniczący zarządził ponowne głosowanie wyniki którego następujące:

b) Kandydaci do Zarządu:

1) pani Zofia Kobecka, urzędniczka państwowa, 34 głosów.

2) pan Emanuel Aronowicz, urzędnik dyrekcji P. K. P., 26 głosów. 
c) Do Komisji Rewizyjnej Gminnej wybrani:

1) pan Romuald Kobecki, urzędnik państwowy, 25 głosów.

2) Noe Robaczewski, pułkownik rezerwy W. P., 25 głosów.

3) Józef Kobecki, emeryt państwowy, 22 głosów.

Kandydat

1) p. Józef Kozyrowicz, kupiec, 32 głosów.

Po ogłoszeniu wyników wyborów przewodniczący pan Eliasz Jutkiewicz w imieniu nowo obranego Zarządu Gminy, wyłuszczył historię powstania gminy karaimskiej w Wilnie i podkreślił wybitną i znaczną rolę w pracach przygotowawczych, za czego i szlachetnego rodaka naszego pana Emanuela Kobeckiego, prezesa gminy karaimskiej w Trokach, wyraził hołd całej jego działalności społecznej i zaproponował ogólnemu zebraniu nadanie panu Emanuelowi Kobeckiemu godności honorowego dożywotniego członka gminy karaimskiej w Wilnie, jako propozycja została przyjęta przez aklamację wszystkich zgromadzonych na zebraniu. O powyższej uchwale polecono prezydium zebrania zakomunikować panu E. Kobeckiemu. Walne Zgromadzenie na wniosek J. Zajączkowskiego poleciło prezydium zebrania złożyć odpis niniejszego protokołu do Urzędu Wojewódzkiego.

Wobec wyczerpania porządku dziennego przewodniczący o godzinie jedenastej wieczorem zamknął zebranie.

\section{[16 r]}

\section{Protokół \\ walnego zgromadzenia czlonków karaimskiej gminy wyznaniowej w Wilnie z dn. 13 marca r. $1927^{5}$.}

Lista wykazuje obecność osób uprawnionych: 54 .

Prezes zarządu karaimskije gminy wyznaniowej pan Eliasz Jutkiewicz o godz. 19 m. 50 zagaił obrady walnego zgromadzenia, oświadczając, że w myśl statutu gminy obecne walne zgromadzenie, wyznaczone na godz. 19-tą, jako powtórne, ważne jest przy dowolnej ilości obecnych członków. Następnie pan E. Jutkiewicz ogłasza porządek dzienny obrad, przyjęty do wiadomości przez Urząd Komisarza Rządu na m. Wilno pismem z dn. 8 marca r. b. za № 653/V/SPW/27:

1) Wybory Zarządu Gminy,

2) O wyegzekwowaniu legatu b. p. M. Durunczy,

3) Sprawy bieżące,

5 LVMAB, F 301-449, fol. 16 r - 16 v. 
i proponuje obrać prezydium zgromadzenia. Do Prezydium Zgromadzenia zostali obrani przez aklamację na przewodniczącego pan Ananiasz Rojecki i na sekretarza pan Michał Kobecki.

Na wniosek przewodniczącego, zgromadzenie uczciło pamięć honorowego członka wileńskiej karaimskiej gminy wyznaniowej b.p. Emanuela Kobeckiego przez powstanie z miejsc.

Następnie przystąpiono do obrad nad punktem pierwszym przyjętego porządku dziennego.

Na wniosek pana Izaaka Zajączkowskiego, zgromadzenie uchwaliło jednomyślnie przy dwóch wstrzymujących się ustalić liczbę członków zarządu, powołanych z wyboru, w ilości sześciu, co łącznie z jednym członkiem zarządu, wchodzącym doń ex officio, daje liczbę nieparzystą członków siedmiu.

Przewodniczący otwiera listę kandydatów do zarządu gminy.

Po zgłoszeniu przez zgromadzonych dwunastu kandydatów, lista na wniosek pana Michała Kobeckiego została zamknięta.

Do Prezydium wpłynął wniosek pana Izaaka Zajączkowskiego o niebranie pod uwagę odmów kandydatów przed przeprowadzeniem wyborów, kwestię zaś zgody podjać dopiero po ogłoszeniu wyników głosowania. Po krótkiej dyskusji powyższy wniosek został przyjęty przez zgromadzenie.

Na wniosek pana Izaaka Zajączkowskiego przewodniczący ustala sposób [16 v] głosowania, a mianowicie: każdy z wyborców winien umieścić na kartce sześć nazwisk osób, wysuwanych na członków zarządu gminy i dwa nazwiska osób, wysuwanych na kandydatów do powyższych członków.

Do komisji obrachunkowej prezydium zgromadzenia powołało: panią Marię Dubinską, i pana Szymona Nowickiego i Eliasza Szpakowskiego. Celem wypełnienia kartek ogłoszono pięciominutową przerwę.

Wyniki głosowania przedstawiały się, jak następujące:

\begin{tabular}{l|l|l}
\multirow{2}{*}{\multicolumn{1}{c}{ Imię i nazwisko }} & \multicolumn{2}{c}{ Ilość otrzym. głosów } \\
\cline { 2 - 3 } & Na członka & Na kandyd. \\
\hline p. Izaak Zajączkowski & 44 & 0 \\
\hline p. Józef Łopatto & 41 & 3 \\
\hline p. Eliasz Jutkiewicz & 37 & 1 \\
\hline p. Ananiasz Rojecki & 37 & 1 \\
\hline p. Izaak Rojecki & 24 & 6 \\
\hline p. Noe Robaczewski & 22 & 10 \\
\hline p. Awenir Kobecki & 19 & 10 \\
\hline p. Ksenia Abkowiczówna & 18 & 13 \\
\hline p. Emanuel Aranowicz & 10 & 10 \\
\hline p. Romuald Kobecki & 8 & 10 \\
\hline p. Owadiusz Pilecki & 8 & 10 \\
\hline p. Aleksander Tynfowicz & 3 & 7
\end{tabular}


Wobec tych wyników zachodzić miały dwie komplikacje:

1) Zakwestionowano przez pana Izaaka Zajączkowskiego, że tylko czterej członkowie zarządu otrzymali kwalifikowaną większość głosów, pozostali zaś z braku tejże nie mają prawa na objęcie godności członkowskiej, jak również kandydaci.

2) Wysunięto przez pana Michała Kobeckiego brak logiczności w przeprowadzonych wyborach, widoczny stąd, że na kandydatów zostali obrani ci, którzy mieli zaledwie 13 głosów kandydackich, wtedy gdy mający 19 lub 18 głosów członkowskich nie liczą się wybranymi nawet na kandydatów.

Powyższe kwestie wywołały długą i ożywioną dyskusję, w której brali udział panowie I. Zajączkowski, E. Jutkiewicz, E. Szpakowski, N. Robaczewski, zarówno jak i członkowie prezydium zgromadzenia.

Po dyskusji przewodniczący ogłasza, że wybranymi zostali:

1) na członków Zarządu: panowie Izaak Zajączkowski, Józef Łopatto, Eliasz Jutkiewicz i Ananiasz Rojecki. Panowie E. Jutkiewicz i A. Rojecki nie przyjmują wyboru. Pan I. Zajączkowski przyjmuje wybór warunkowo, pan J. Łopatto przyj[I7 r] muje wybór bez zastrzeżeń. Wobec tego przewodniczący zarządza dodatkowe wybory. Panowie Zajączkowski i Łopatto, aby ułatwić ułożenie wspólnej listy, zrzekają się swego wyboru.

Wpłynęły dwa wnioski:

1) Wniosek pana Michała Kobeckiego o unieważnienie wyborów i o zamknięcie obrad z odroczeniem nowych wyborów do następnego zgromadzenia. Wniosek ów został dopełniony przez pana Eliasza Jutkiewicza z tym, aby następne zgromadzenie odbyło się dn. 20 b. m.

2) Wniosek pana Noego Robaczewskiego o przeprowadzenie natychmiastowych wyborów z unieważnieniem poprzednich.

Za pierwszym wnioskiem głosowało osób 13, za drugim 24, reszta się wstrzymała się przed głosowaniem, przeto wniosek pierwszy upadł.

Celem omówienia kandydatur ogłoszono dziesięciominutową przerwę, po których upłynięciu przewodniczący wznowił obrady zgromadzenia.

Na wniosek pana Eliasza Jutkiewicza uchwalono uzyskać zgodę kandydatów przed głosowaniem. Z listy, składającej się z 12 nazwisk żaden z kandydatów nie udzielił swej zgody na objęcie godności członka zarządu w razie ewentualnego obrania. Po długich próbach ułożenia listy kandydatów, zgłoszona została przez pewną grupę wyborców lista wyborcza № 1, składająca się z ośmiu osób, wysuwanych do zarządu gminy i trzech osób do komisji rewizyjnej. Uzyskano zgodę kandydatów, prócz wystawionego do komisji rewizyjnej G. A. Kobeckiego, nieobecnego na zgromadzeniu.

Po przeprowadzeniu tajnych wyborów, przewodniczący ogłosił wyniki: za listą № 1 głosowało 35 wyborców (w tym trzech za tą listą, wyłączając kandydata Szymona Nowickiego), przeciw jedna osoba, białych kartek 5. 
Obranymi do Zarządu zostali:

Na członków:

1) Izaak Zajączkowski

2) Józef Łopatto

3) Noe Robaczewski

4) Romanowa Kobecka

5) Izaj [sic] Rojecki

6) Emanuel Aranowicz

Na kandydatów panowie:

1) Szymon Nowicki

2) Zachariasz Tynfowicz

Do komisji rewizyjnej panowie:

1) Gabr[iel] Aleks[ander] Kobecki

2) Owadiusz Pilecki

3) Ksenia Abkowiczówna

Zgromadzenie przyjęło oklaskami ogłoszony wynik głosowania.

Na wniosek pana M. Kobeckiego rozpatrzenie pozostałych punktów porządku dziennego obrad przeniesiono na następne zgromadzenie, które ma zwołać [17 v] świeżo powołany zarząd gminy.

O godz. 23 min. 05 zgromadzenie zostało zamknięte.

[I]

\section{Program konferencji delegatów gmin karaimskich Rzeczypospolitej Polskiej odbyć się mającej w dniach II i 12 czerwca 1927 r. w Haliczu ${ }^{6}$.}

Pierwszy dzień konferencji dnia 11 czerwca 1927 r.

1. O godzinie 9 uroczyste nabożeństwo w kienesie karaimskiej w Haliczu odprawione przez nestora duchowieństwa karaimskiego w Polsce i zasłużonego hazzana Wileńskiej karaimskiej kienesy przewielebnego Feliksa Maleckiego.

2. Po nabożeństwie wspólny obiad z powitalnym przemówieniem pana dra Zachariasza Nowachowicza adwokata w Haliczu.

3. O godz. 3 po południu otwarcie konferencji przemówieniem prezesa delegacji gminy halickiej pana dra Zachariasza Nowachowicza.

4. Wybór Prezydium konferencji i dwóch sekretarzy.

5. Złożenie hołdu Rzeczypospolitej i wysłanie telegramu hołdowniczego na ręce Pana Prezydenta Rzeczypospolitej.

6 LVMAB F 301-455, fol. 1 r, 2 r. 
6. Przemówienia delegatów innych gmin karaimskich ewentualnie gości i zgłaszanie referatów poszczególnych delegatów na temat spraw dotyczących Karaimów.

\section{Drugi dzień konferencji dnia 12 czerwca 1927}

1. Sprawa wyboru hachama trockiego na zasadach art. 1266 t. XI zbioru pr. ros. i przyjęcie regulaminu wyboru hachama wraz z omówieniem wszelkich szczegółów wyborów, referowana przez delegatów poszczególnych gmin.

2. Referat p. Zaracha Zarachowicza w sprawie „Tymczasowych Przepisów w stosunku Rządu do Związku Religijnego karaimskiego i o zasadach zarządzania sprawami duchownymi Karaimów jako podstawy organizacji i rozwoju gmin karaimskich wraz z dyskusją na ten temat.

3. Referat o prasie i wydawnictwach karaimskich (delegat trocki lub wileński).

\section{Przerwa Obiadowa}

4. Szkolnictwo karaimskie w szkołach wyznaniowych i nauczanie religii karaimskiej w szkołach publicznych, postulaty Karaimów w tych sprawach w stosunku do Rządu wraz z przedstawieniem obecnej sytuacji [2] pod względem rozwoju kulturalnego karaimów ze szczególnym uwzględnieniem języka liturgicznego i macierzystego.

5. Wnioski i interpelacje.

Referat podzielony między wszystkie gminy.

6. Zamknięcie zjazdu.

7. Przedstawienia amatorskie.

Odegrane będą:

1. „Eki tirlik” (Dwa światy)

Komedia w pierwszym akcie Szymona Firkowicza.

2. „Dostu jiwnin” (Przyjaciel domu).

Komedia w dwóch aktach Szymona Firkowicza.

$[4 \mathrm{r}]$

\section{Protokół konferencji Gmin karaimskich w Polsce z dnia II czerwca $1927^{7}$}

Program załączony pod $1 /$ do protokołu.

O godzinie 4 po południu delegat gminy halickiej pan dr Zachariasz Nowachowicz zagaja obrady.

$7 \quad$ LVMAB F 301-455, fol. 4 r - 5 v. 
Obecni:

Delegat województwa stanisławowskiego i M. W. R. i O. P. JWP. Leon Kochański, kierownik oddziału wyznaniowego.

JWP. poseł na Sejm Henryk Mianowski

JWP. Radca Firich

Przewielebny hazzan Feliks Malecki delegat Wilna

JWP. dr Izaak Zajączkowski adwokat

JWP. Józef Zajączkowski z Trok

JWP. Dawid Nowicki

JWP. Aleksander Firkowicz z Łucka

JWP. Zachariasz Szpakowski

JWP. Dr Zachariasz Nowachowicz z Halicza

Członkowie zarządu gminy halickiej Samuel Samuelowicz, Lech Eszwowicz, Nowak Abrahamowicz, Ezua Lechowicz, i Zarach Zarachowicz, oraz hazzan kienesy halickiej Isak Abrahamowicz i młodszy hazzan Marek Leonowicz jako eksperci w sprawach wyznaniowych.

$\mathrm{Na}$ propozycję pana dra Nowachowicza wybrano prezydium w następującym składzie:

Izaak Zajączkowski przewodniczący

Aleksander Firkowicz i Dawid Nowicki jako asesorowie

Zachariasz Szpakowski i Zarach Zarachowicz jako sekretarze

JWP. P. Lech Kochański, Henryk Mianowski i Antoni Firich jako honorowi asesorowie.

Przewodniczący Izaak Zajączkowski obejmuje przewodnictwo i otwiera obrady. Odczytane telegramy prof. Kowalskiego, Zarządu Duchownego w Trokach i Zarządu gminy wileńskiej.

Uchwalono wysłać depesze hołdownicze treści następującej:

1/ Do Pana Prezydenta Rzeczypospolitej Warszawa; „Konferencja organi- [4 v] zacyjna delegatów gmin karaimskich w Polsce obradująca w dniu dzisiejszym w Haliczu składa wyrazy hołdu i zapewnienia najgłębszej czci dla osoby Pana Prezydenta oraz bezwzględnego przywiązania do Państwa Prezydium Zajączkowski.

2/ Do Pana Marszałka Piłsudskiego Warszawa: „Konferencja organizacyjna delegatów gmin karaimskich w Polsce obradująca w dniu dzisiejszym w Haliczu składa wyrazy hołdu i zapewnienia najgłębszej czci dla osoby Pana Marszałka oraz bezwzględnego przywiązania do Państwa Prezydium Zajączkowski.”

3/ Minister Dorubski, Warszawa: „Konferencja organizacyjna delegatów gmin karaimskich w Haliczu przesyła Panu Ministrowi wyrazy czci i wdzięczności oraz zapewnienia bezwzględnego przywiązania do Państwa, Prezydium Zajączkowski.” 
4/ Wojewoda Korsak, Stanisławów: „Konferencja organizacyjna delegatów gmin karaimskich w Haliczu Panu Wojewodzie wyrazy czci i wdzięczności oraz zapewnienia bezwzględnego przywiązania do Państwa. Prezydium Zajączkowski.”

Na tym obrady w pierwszym dniu konferencji zakończono, z tym, że konferencja po dyskusji akceptowała program konferencji.

Drugi dzień konferencji dnia 12 czerwca 1927

Obecni wszyscy członkowie konferencji, jak w dniu 11 czerwca 1927.

Na wniosek p. Antoniego Firicha powołano p. Leona Szulimowicza z głosem doradczym.

Na wniosek pana I. Zajączkowskiego uchwalono wysłać wyrazy pozdrowienia i czci dla przebywającego na wygnaniu hachana eupateryjskiego Sereja Szapszała.

Na wniosek pana dra Nowachowicza uchwalono wysłać adresy do p. dra Tadeusza Kowalskiego w Krakowie, p. dra Okulicza, komisarza Rządu na miasto Wilno, starosty pow. wileńskiego-trockiego i starosty łuckiego i stanisławowskiego, oraz depesze identyczne, jak do wojewody stanisławowskiego i wołyńskiego, na wniosek Leona Szulimowicza uchwalono wysłać depesze identyczne jak do Pana Prezydenta Rzeczypospolitej na ręce Panów Marszałków Sejmu i Senatu.

Następnie p. dr Nowachowicz poświęca gorące słowa wspomnienia panu Janowi Grzegorzewskiemu i Emanuelowi Kobeckiemu i na wniosek p. dra [5 r] Nowachowicza konferencja uczciła ich pamięć przez powstanie i minutowe milczenie.

Przystąpiono do porządku dziennego.

Po referacie pana Izaka Zajączkowskiego i po dyskusji, w której zabierali głos delegat Rządu, poseł Mianowski, Radca Firich, dr Nowachowicza, Zarach Zarachowicz, Zachariasz Szpakowski i inni uchwalono jednomyślnie Regulamin wyboru Hachama załączony jako aneks do niniejszego protokołu.

Na propozycję przewodniczącego zmieniono porządek dzienny w ten sposób, ze przed punktem drugim wstawiono punkt trzeci.

Referuje sprawę przewodniczący pan Izaak Zajączkowskki. - W. P. J. Zajączkowski przedstawia do uchwalenia następujące rezolucje:

1) Konferencja uchwala wyrazić podziękowanie p. dr Prof. Kowalskiemu za troskliwą opiekę i współpracownictwo [s] w wydawnictwie „Myśl karaimska” i obrać go na honorowego członka Komitetu redakcyjnego tego wydawnictwa.

2) Konferencja uznając „Myśl Karaimskąa jako jedyny organ urzędowy Związku Wyznaniowego Karaimskiego w Polsce stojącego ściśle na gruncie Państwowości polskiej uprasza Rząd o zasilenie wydawnictwa potrzebną subwencją, polecając wykonanie tej uchwały Zarządowi gminy karaimskiej w Wilnie.

Powyższe dwie rezolucje przyjęto jednogłośnie. Na wniosek p. dra Nowachowicza przyjęto jednogłośnie rezolucję następującej treści: Zebrani delegaci wszystkich 
gmin karaimskich na konferencji w Haliczu uznają, że obecnie wyrazicielem myśli i przekonań Karaimów w Polsce na gruncie państwowości i kultury polskiej jest wileńska „Myśl Karaimska” i potępia ją próby wprowadzenia w życie karaimskie dysharmonii na tle ideowym w rodzaju jednodniówki „Nasza Myśl” w języku rosyjskim wydanej w Wilnie 1 czerwca br. przez p. Odiusza Pileckiego.

Pan Zarachowicz referuje w sprawie Tymcz. przepisów o stos. Rządu do Związku Religijnego Karaimskiego i o zasadach zarządzania sprawami duchownymi Karaimów zostaje poruszoną przez referenta pana Zarachowicza kwestia przyjmowania udziału w wyborach duchownych osób karaimów bez różnicy płci. W tej sprawie zabierał głos w charakterze eksperta przewielebny pan Malecki, następnie hazzan pan Abrachamowicz, następnie przemawiali w tej sprawie panowie Leonowicz, I. Zajączkowski i Szpakowski.

Po dłuższej dyskusji przeprowadzanej na ten temat konferencja uchwaliła jednogłośnie przyjąć wniosek pana Szpakowskiego treści następującej: [5 v] Ostateczne ustalenie tekstu przepisów prawnych, regulujących organizację gmin wyznaniowych karaimskich w Polsce, odroczyć do czasu wyborów hachana, który w porozumieniu z poszczególnymi gminami wyznaniowymi karaimskimi w Polsce takowe opasuje.

Na tym dyskusja zastała wyczerpana i przeszli do obrad dalszych wedle programu konferencji odnośnie do punktu czwartego programu.

W kwestii te przemawiał pan Józef Zajączkowski, który przedstawił wniosek treści następującej: Przyjmując pod uwagę opłakany stan szkolnictwa karaimskiego oraz brak środków w poszczególnych gminach karaimskich na utrzymanie etatowego nauczyciela należy zwrócić się z petycją do miarodajnych czynników rządowych w celu wyjednania odpowiedniej rocznej dotacji na wynagrodzenie nauczycieli religii karaimskiej w języku karaimskim oraz jednorazowego subsydium na wydawnictwo podręczników dla nauczania religii karaimskiej i języka karaimskiego. Wniosek ten został jednogłośnie przyjęty.

Następnie konferencja delegatów na wniosek p. Izaaka Zajączkowskiego, uwzględniając opłakany stan ekonomiczny społeczeństwa karaimskiego i wywołanego u niego zubożenia wskutek wojny, a wskutek tego powstałej niemożności utrzymywania własnymi funduszami gmin, kienes i duchowieństwa, uchwaliła polecić Zarządowi gminy karaimskiej w Wilnie interweniowanie u władz i przygotowanie odpowiedniego memoriału do władz, w celu wyjednania u tychże wstawienia do budżetu państwowego odpowiedniej kwoty.

Na wniosek pana Firicha konferencja uchwaliła: Ze względu na interesy Państwa Polskiego i jego świetne tamże tradycje i wielkie obowiązki na przyszłość, uwzględniając okoliczność, że w Wileńszczyźnie zamieszkuje większa ilość narodów wschodnich Karaimów i Muzułmanów w interesie Państwa Polskiego.

„Zjazd apeluje do Rządu Polskiego o utworzenie przy Uniwersytecie Wileńskim katedry języków, historii i kultury wschodniej, jako podstawy pod przyszłą akademię orientalną w Polsce.” 
Następnie przemówienia pożegnania wygłosili: pan Izaak Zajączkowski, dr Zachariasz Nowachowicz, Józef Zajączkowski, Antoni Firich i Ezua Leonowicz, po czym przewodniczący ogłasza konferencję zamkniętą o godzinie 8.15 [dnia] 20.15. Na zakończenie odśpiewano hymny narodowe polskie. I. Zajaczkowski przewodniczący $\mathrm{mp}^{8}$, Kochański Leon mp, delegat wojewódzki M. Wyzn. R. i O. P., Inż. Henryk Mianowski mp, poseł, F. Malecki mp, D. Nowicki mp, A. Firkowicz mp, Marek Leonowicz mp, Samuel Samuelowicz mp, Izak Abrachamowicz mp, T. Zachariasz Nowachowicz mp, Leon Rszwowicz mp, Nowach Abrachamowicz mp, Ezua Leonowicz mp, Z. Szpakowski mp, Zarach Zarachowicz mp, inż. A. Firich.

\section{[6 r]}

\section{Aneks do protokołu konferencji delegatów gmin karaimskich w Polsce z dnia II i 12 czerwca 1927 w Haliczu ${ }^{9}$}

Regulamin wyborów hachama, jako najwyższej osoby duchownej karaimów zamieszkujących w obrębie Rzeczypospolitej Polskiej.

Art. 1

Hacham jest najwyższą duchowną osobą karaimów zamieszkujących w obrębie Rzeczypospolitej Polskiej.

Art. 2

Hachama wybierają wszystkie gminy karaimskie w obrębie Rzeczypospolitej Polskiej. W tym celu każda z tych gmin deleguje jednego swego przedstawiciela.

Wybór ma się odbywać w siedzibie gminy wyznaniowej Troki.

Art. 3

Wybory hachama odbywają się w drodze tajnego głosowania w obecności przedstawiciela Rządu. W tym celu Zarząd Duchowny przynajmniej na 14 dni przed wyborami zawiadomi w sposób pisemny Urząd Wojewódzki w Wilnie.

Najdalej na cztery tygodnie przed wyborami ustali Zarząd Duchowny w porozumieniu z gminami wyznaniowymi karaimskimi dzień wyborów hachama.

Art. 4

Hachama wybierają obecni delegacji gmin bezwzględną większością głosów, w razie zaś równości głosów rozstrzyga los wyciągnięty przez przewodniczącego wyborów.

Art. 5

Delegaci Gmin wybierają z pośród siebie przewodniczącego wyborów.

$8 \quad$ Mp, skrót z j. łacińskiego manu propria = ręką własną.

9 LVMAB F 301-455, fol. 6 r - 6 v. 
Art. 6

Po dokonaniu głosowania wszyscy wyborcy oraz przedstawiciel Rządu podpisują akt wyborczy.

Najdalej do trzech dni od chwili wyborów hachama przewodniczący wyborów przedkłada w sposób pisemny wynik wyborów wojewodzie wileńskim.

O ile w ciągu czterech tygodni od chwili zawiadomienia o wyniku wyborów hachama Rząd nie podniesie sprzeciwu co do osoby obranego wybór, staje się prawomocnym.

Po prawomocności wyborów składa hacham na ręce przedstawiciela Rządu uroczyste ślubowanie lojalności i wierności dla Państwa. [6 v]

Nowo wybranemu hachamowi przysługuje prawo odnieść się z prośbą do pana wojewody w Wilnie o delegowanie przedstawiciela Rządu w celu fundowania w charakterze uroczystego świadka przy obejmowaniu przez Zarządu spraw wyznaniowych karaimów.

Art. 7

Sprawę uposażenia hachama rozstrzyga Rząd.

Art. 8

Siedzibą Hachama będzie Wilno lub Troki, stosownie do jego uznania osiągniętego w porozumieniu z Rządem.

Art. 9

Aż do czasu wprowadzenia przepisów prawnych, regulujących organizację gmin karaimskich w Polsce będzie działanie hachama regulowane normami ustalonymi w księdze czwartej tom IX cz. I. Zb. pr. ros. wraz ze zmianami, wprowadzonymi przez niniejszy regulamin.

[50 r]

\section{Protokół \\ walnego zgromadzenia członków karaimskiej gminy wyznaniowej w Wilnie w dniu 8-go października r. $1927^{10}$}

O godz. 18 m. 45 pan prezes zarządu gminy wyznaniowej zagaił obrady zgromadzenia członków gminy, przystępując do wyborów prezydium zgromadzenia.

$\mathrm{Na}$ przewodniczącego zgromadzenia powołano przez aklamację pana Eliasza Kalfę, na sekretarzy zaś panów Owadiusza Pileckiego i Michała Kobeckiego.

Przyjęto porządek dzienny składający się z następujących punktów:

1) Wybory delegata na Ogólnopolski Zjazd Karaimów w Trokach,

2) Wolne wnioski.

10 LVMAB F 301-449, fol. 50 r - 51 r. 
Przed rozpoczęciem obrad nad porządkiem dziennym zabrał głos pan prezes I. Zajaczkowski w sprawie obchodu rocznicy wyzwolenia Wilna przez wojska polskie. Na wniosek zarządu gminy jednomyślnie powzięto następującą uchwałę, oraz polecono panu prezesowi I. Zajączkowskiemu złożyć ją na ręce pana wojewody na przyjęciu w urzędzie wojewódzkim: „Walne Zgromadzenie członków Karaimskiej Gminy Wyznaniowej w Wilnie w przeddzień rocznicy wyzwolenia prastarego grodu Giedyminów Wilna z przemocy litewskiej oraz faktycznego połączenia tej ziemi, od wieków zamieszkałej przez naszych przodków, z Macierzą, składa na ręce JW. Pana wojewody wileńskiego Wł. Raczkiewicza wyrazy hołdu i przywiązania dla osoby Pana Marszałka Polski Józefa Piłsudskiego oraz wyrazy wielkiego uznania dla Bohaterów, którzy dokonali ten świetny czyn i dla przedstawicieli Rządu Najjaśniejszej Rzeczypospolitej Polskiej, którzy umożliwili Karaimom rozwój ich życia kulturalno-religijnego w najszerszym zakresie. Niech żyje Polska”. Pan prezes zarządu oznajmił, iż w dn. 9 b. m. odbędzie się uroczyste nabożeństwo w kienesie wileńskiej z okazji rocznicy wyzwolenia Wilna.

Następnie zabrał głos pan Eliasz Jutkiewicz w celu poinformowania zgromadzenia o wymianie listów między p.o. hachama karaimskiego panem Szymonem Firkowiczem w Trokach, a wojewodą wileńskim panem Racz- [5o v] kiewiczem z powodu choroby przebytej przez p. wojewodę.

Po wysłuchaniu powyższych informacji zgromadzenie przystąpiło do obrad nad punktem pierwszym porządku dziennego.

Na wniosek p. Ananiasza Zajączkowskiego przyjęto następujący regulamin wyborów delegata na zjazd: „Walne Zgromadzenie uchwaliło następujący tryb postępowania wyborów delegata na zjazd: 1) Otwiera się lista kandydatów na delegata, przy czym po wyczerpaniu zgłaszanych nazwisk zostaje zamknięta. 2) Każdy z obecnych kandydatów na delegata wygłasza ogranicza się 20 min. 3) Otwiera się nad tymi przemówieniami dyskusja, w której nie mogą brać udział kandydaci na delegata. 4) Po wyczerpaniu dyskusji udziela się głosu kandydatom na delegata dla odpowiedzi na poprzednią dyskusję. Czas przemówienia ogranicza się do $10 \mathrm{~min}$. 5) Po wybraniu komisji dla liczenia głosów ogłasza się przerwa dziesięciominutowa, poczym następuje tajne głosowanie, celem wyboru delegata na zjazd karaimski dn. 23. X.".

Przyjęto również poprawkę do punktu piątego o ograniczeniu czasu przemówienia do 10 minut i ilości przemówień dla jednej osoby do dwóch razy.

Pan Eliasz Jutkiewicz zapytuje Zarząd Gminy, czy nie będzie ogłoszony referat w sprawie zjazdu. Pan prezes zarządu, odpowiada z urzędu, oświadcza że wspomniany referat był wygłoszony na poprzednim zgromadzeniu informacyjnym.

W myśl przyjętego regulaminu otwarto listę kandydatów, na którą zgłoszono dwie kandydatury:

1) p. Izaaka Zajączkowskiego i

2) p. Eliasza Jutkiewicza. 
Pan Izaak Zajaczkowski w swym expose oświadczyl, że na zjeździe, podczas wyborów hachama, będzie popierał kandydaturę p. Szapszała (Seraja - Beja) znanego działacza społecznego karaimskiego, byłego hachama Karaimów krymskich, obywatela państwa perskiego, zamieszkałego obecnie w Konstantynopolu.

Pan Eliasz Jutkiewicz wypowiedział się również za kandydaturę pana Szapszała z zastrzeżeniem, że popierać ją będzie tylko w razie przyrzeczenia przez pana Szapszała ścisłej współpracy na stanowisku hachama z panem Feliksem Maleckim obecnie p. o. Hazzana kienesy wileńskiej. [5I r]

Po przemówieniach kandydatów wywiązała się dyskusja między członkami zgromadzenia, którą po przemówieniu szeregu osób, zamknięto na wniosek pana Aleksandra Kobeckiego.

Do Komisji skrutacyjnej powołano panów Aleksandra Abkowicza, Józefa Łabanosa, Ananiasza Rojeckiego i Eliasza Szpakowskiego.

Po dziesięciominutowej przerwie przystąpiono do tajnych wyborów kartkami, których wyniki są następujące:

Z obecnych 87 członków gminy brało udział w głosowaniu kartkami 87.

Za kandydaturą p. Izaaka Zajączkowskiego oddało głosy 49 (czterdzieści dziewięć) osób, a za kandydaturą p. Eliasza Jutkiewicza 38 (trzydzieści osiem) osób.

Ogłoszono wyniki wyborów, mocą których został obrany na delegata pana Izaak Zajączkowski, na zastępcę pan Eliasz Jutkiewicz.

Ogłoszono wyniki wyborów, mocą których został obrany na delegata p. Izaak Zajączkowski, na zastępcę p. Eliasz Jutkiewicz.

Ogłoszenie wyborów przyjęte zostało hucznymi oklaskami.

Wolne wnioski.

P. Owadiusz Pilecki, jako członek komisji rewizyjnej gminy, prosi o wybranie dwóch członków komisji na miejsce p. G. A. Kobeckiego, który nie udzielił swej zgody na pełnienie powyższych obowiązków i panny Ksenii Abkowiczówny, która wyjechała z Wilna.

Przez aklamację obrano p. p. J. Kozyrowicza i p. Eliasza Kobeckiego.

O godz. 22 zgromadzenie zostało zamknięte.

[9r]

Protokół pierwszego ogólnopolskiego zjazdu Karaimów w Trokach,
odbytego dnia 23-go października 1927 roku

Obecni na zjeździe:

JW. Pan wojewoda wileński Raczkiewicz Władysław, panowie naczelnicy: Dworakowski, major Kirtiklis, dyrektor Siła-Nowicki, Piotrowicz, sekretarz

${ }_{11} \quad$ LVMAB F 301-455, fol. 9 r - 10 r. 
Staniewicz, prezes syndykatu dziennikarzy wileńskich w Wilnie, Czesław Jankowski, burmistrz m. Trok Łakowicz i inni zaproszeni goście.

Gminy karaimskie reprezentowali oficjalnie:

Gminę trocką p. Emil Kobecki.

Gminę halicką dr Zachariasz Nowachowicz.

Gminę wileńską Izaak Zajączkowski.

Gminę łucką Zachariasz Szpakowski.

Ponad byli obecni na zjeździe: p. o. hachama trockiego hazzan Szymon Firkowicz i liczni reprezentanci wszystkich gmin karaimskich.

Po odprawieniu przez p.o. hacham Szymona Firkowicza solennego nabożeństwa w trockiej kienesie na pomyślność R.P. i Wysokiego Rządu, zebrali się wszyscy uczestnicy zjazdu w sali zebrań domu gminnego.

Zebranie zagaił p.o. hachama pan Szymon Firkowicz podniosłym przemówieniem, wita jak przedstawicieli władz i wszystkich zebranych oraz wyjaśnia cel tego zebrania. Na jego wniosek uproszono pana W. Raczkiewicza wojewodę wileńskiego o przyjęcie honorowego przewodnictwa tego zjazdu, a przyjęcie przez pana wojewodę tego przewodnictwa przywitano ogólnym aplauzem. Na wniosek pana Szymona Firkowicza wybrano na przewodniczącego zjazdu jednogłośnie przez aklamację pana dra Zachariasza Nowachowicza, który na sekretarza powołał pana Zachariasza Szpakowskiego. Przewodniczący zjazdu pan dr Zachariasz Nowachowicz w przemówieniu swoim podziękował za wybór, a następnie złożył podziękowanie panu wojewodzie za wzięcie udziału i wszystkim obecnym w tym zebraniu. W dalszym ciągu przedstawił stosunek faktyczny karaimów w Polsce idei państwowości polskiej na kresach wschodnich oraz historyczną genezę tego stosunku, [9 v] podziękował na ręce pana wojewody Rządowi Polskiemu za okazywaną pieczołowitość dla spraw karaimskich oraz złożył zapewnienie w imieniu wszystkich karaimów w Polsce, że ideą przewodnią dla pracy na kresach wschodnich dla karaimów będą na zawsze interesy narodu polskiego w myśl idei jagiellońskiej. Następnie mówca uzasadnił swoje twierdzenia i oświadczenia historycznymi faktami i wezwał swoich rodaków do dalszego trwania w tej tradycji historycznej polskiej oraz wniósł okrzyk na cześć Najjaśniejszej Rz. P.: Najjaśniejsza Rz. P. Polska niech żyje co zgromadzeni w podniosłem nastroju powtórzyli. W dalszym ciągu przewodniczący Zjazdu odczytał telegramy pp. (... $)^{12}$ oraz list pana starosty wileńskiego. Na wniosek pana Izaaka Zajączkowskiego uchwalono zwrócić się do pana wojewody wileńskiego z prośbą o złożenie Panu Prezydentowi RP, Panu Marszałkowi Piłsudskiemu w imieniu zjazdu ogólno-karaimskiego wyrazów hołdu i przywiązania do Państwa Polskiego; wszystkim, którzy złożyli życzenia zjazdowi podziękowania, panu Ministrowi Spraw Wewnętrznych, panom ministrom złożyć pozdrowienie, zaś za złożone życzenia przesłać podziękowanie. Następnie zabrał

12 Brak nazwisk, zdanie niedokończone. 
głos pan wojewoda i przedstawił w swoim przemówieniu historyczne powstanie osiedli karaimskich w Polsce oraz podniósł, że pracowitość, uczciwość i lojalność Karaimów i narodu wobec Państwa Polskiego znalazły uznanie u królów polskich, którzy obdarzyli ich w nagrodę za te przymioty ziemią i przywilejami. W dalszym ciągu zwrócił uwagę na to, że i obecny Rząd, idąc za tradycją dawniejszych królów polskich, w pewnej mierze odniósł się życzliwie dla spraw karaimskich w tej nadziei, że i Karaimi polscy będą z narodem polskim współpracować w budowaniu i utrwalaniu państwowości polskiej na kresach. W końcu pan wojewoda życzył zjazdowi owocnych wyników pracy. Przemówienie pana wojewody zostało przyjęte hucznymi oklaskami. Pan przewodniczący podziękował panu wojewodzie w imieniu zjazdu za serdeczne ton i życzenia w przemówieniu i wniósł okrzyk na cześć pana wojewody: „Niech żyje”, który to okrzyk całe zebranie wzniosło.

Delegat p. Izaak Zajączkowski zabrał głos. Celem uczczeniu pamięci zmarłych hachamów trockich b.p. Bogusława Kapłanowskiego i Romualda Kobeckiego i innych działaczy karaimskich.

Wspomniał, że na czele tych działaczy dla spraw karaimskich nale [io r] ży postawić zmarłego przed około rokiem b.p. Emanuela Kobieckiego, który na każdym polu objawiał żywe zainteresowanie się i owocną pracą dla spraw karaimskich. W dalszym ciągu nadmienił mówca, że dzisiejszy zjazd jest tylko uwieńczeniem zainicjowanej w tym kierunku pracy bp. Emanuela Kobieckiego, którego głównym celem pracy było zorganizowanie gmin karaimskich. Na wniosek pana Zajączkowskiego uczczono ich pamięć przez powstanie.

Następnie delegaci gmin wraz z panem Wiktorem Piotrowiczem, przedstawicielem Rządu udali się do przyległej kancelarii celem dokonania wyborów hachama, co też nastąpiło, jak świadczy załączony protokół wyborów. Protokół ten odczytano całemu zebraniu.

Pan przewodniczący podziękował panu wojewodzie za łaskawe wzięcie udziału na zjeździe, oraz dalszym zaproszonym gościom i zamknął zjazd z tym, że dalsze obrady delegatów gmin co do spraw połączonych z wyborem hachama odbędzie się wieczorem na konferencji delegatów.

Zakończono w godz. 14:30.

\section{Protokół dalszego ciągu posiedzenia delegatów gmin Karaimskich w Trokach w dniu 23/10/1927 o godz. 6 po południu odbytego na pierwszym ogólnopolskim zjeździe Karaimów w Trokach ${ }^{13}$}

Obecni podpisani:

1) Ułożono treść telegramów i pism wysłać się mających zgodnie z przedpołudniowymi uchwałami zjazdu.

13 LVMAB F 301-455, fol. 10r-10v. 
2) Uchwalono jednogłośnie poruczyć zajęcie się sprawą dalszego porozumiewania się z wybranym hachamem panem Seraja Szapszała oraz wyjednanie u kompetentnych Władz dla p. Serai Szapszała i jego rodziny obywatelstwa polskiego panu delegatowi gminy wileńskiej adwokatowi Izaakowi Zajączkowskiemu, który te obowiązki przyjął.

3) Wysłuchano sprawozdania pana Izaaka Zajączkowskiego w sprawie wyjednania u Rządu subwencji w myśl uchwał z 11/6 i 12/6 1927 na konferencji delegatów gmin karaimskich w Haliczu powziętych.

Na podstawie tego sprawozdania i uwzględniając obecny stan rzeczy w sprawie organizacji gmin karaimskich w Polsce i Zarządu Duchownego karaimskiego w Trokach podpisem zebrani delegaci gmin [Io v] karaimskich w Polsce upoważniają pana mecenasa Izaaka Zajączkowskiego do interweniowania u kompetentnych władz w sprawie subwencji i budżetowych dotacji na cele gmin karaimskich i ich duchowieństwa oraz do podjęcia wyasygnować się mającej przez Rząd kwoty na pokrycie kosztów pierwszego, ogólnopolskiego zjazdu karaimów w Trokach i na potrzeby kulturalno oświatowe polskich karaimów.

4) Zebrani delegaci gmin karaimskich uchwalają jednogłośnie przesłać odpisy protokołu pierwszego ogólnopolskiego zjazdu karaimskiego w Trokach w dniu 23/10 odbytego i protokołu wyboru hachama i niniejszego protokołu do województwa w Wilnie oraz wszystkim czterem gminom karaimskim w Polsce - zaś oryginalne protokoły tego zjazdu - wyboru hachama i niniejszy protokół oddać panu delegatowi Izaakowi Zajączkowskiemu w przechowanie z tym, że tenże te protokoły wraz z oryginalnymi protokołami Konferencji w Haliczu z dnia 11 czerwca i 12 czerwca 1927 złoży w należytym czasie do aktów Karaimskiego Zarządu Duchownego we Trokach.

Na tym prace pierwszego ogólnopolskiego Zjazdu w Trokach zakończono.

Przewodniczący dr Zachariasz Nowachowicz.

Emil Kobecki delegat gminy trockiej.

Izaak Zajaczkowski delegat gminy wileńskiej.

Zachariasz Szpakowski delegat gminy łuckiej.

\section{[II r]}

\section{Protokół z posiedzenia delegatów gmin karaimskich w Polsce, odbytego dnia 23 października 1927 r. w Trokach, w sprawie wyborów hachama trockiego ${ }^{14}$}

Obecni:

jako przedstawiciel Rządu p. Wiktor Piotrowicz, kierownik Oddziału Wyznaniowego województwa wileńskiego,

14 LVMAB F 301-455, fol. $11 \mathrm{r}-11 \mathrm{v}$. 
Delegat gminy trockiej p. Emil Kobecki, delegat gminy halickiej p. dr Zachariasz Nowachowicz, delegat gminy wileńskiej p. Izaak Zajączkowski i

delegat gminy łuckiej p. Zachariasz Szpakowski.

Przewodniczącym posiedzenia obrany został jednogłośnie pan dr Zachariasz Nowachowicz, który na sekretarza pana Zachariasza Szpakowskiego powołał.

Następnie delegaci wszystkich gmin przekładają swoje pełnomocnictwa których prawidłowość stwierdzono. Na wniosek przewodniczącego stwierdzono, iż przepisanym formalnościom co do zwołania posiedzenia wyborczego, zawiadomienia o tym, że Rząd, który na to posiedzenie zezwolił, zadość uczyniono.

Na wniosek pana Emila Kobieckiego otworzono dyskusję na temat kandydatur na hachana trockiego i wezwano delegatów do zgłoszenia stosownych kandydatów, a po ożywionej dyskusji przyjęto do wiadomości zgłoszoną do gminy wileńskiej kandydaturę pana Seraja bej Szapszała, syna Marka, byłego tawrydzko-odesskiego hachana karaimskiego, którego wszyscy delegaci w swoich oświadczeniach uznają jako odpowiedniego i kwalifikowanego kandydata na stanowisko trockiego hachana. Innych kandydatów nie zgłoszono, a pan przewodniczący zaprasza, jako sekretarza do wyborów hachana pana Szymona Firkowicza, p.o. hachana trockiego, poczym wszyscy czterej delegacji wyborcy, po kolejnym wywołaniu ich nazwisk i imion złożyli po jednej kartce głosowania na ręce pana sekretarza w obecności pana przedstawiciela Rządu i mandatariuszy gmin karaimskich, jako wyborców, a po skonstatowaniu prawidłowej ilości oddanych kart i po obliczeniu głosów przez sekretarza w obecności pana przedstawiciela Rządu i wyborców stwierdzono, że pana Seraja bei Szapszał, syn Marka, otrzymał głosy wszystkich delegatów gmin karaimskich w ilości czterech głosów, i że w ten sposób hachanem trockim wybrany został jednogłośnie pana Seraja bei Szapszał, syn Marka, były karaimski hachan taurydzko-odesski, co [II v] ogłoszono. Uchwalono zawiadomić wybranego hachana o jego wyborze i prosić go o przysłanie oświadczenia, przyjmującego godność hachana trockiego.

Pan przewodniczący oświadcza na interpelację panów delegatów, że dalszym formalnościom wyborów zgodnie z regulaminom, zadość uczynił.

Na tym posiedzenie zakończono o godzinie 2 po południu.

Wiktor Piotrowicz Kierownik Oddziału Wyznań

Emil Kobecki, delegat gminy trockiej.

Izaak Zajączkowski, delegat gminy wileńskiej.

Zachariasz Szpakowski, delegat gminy łuckiej i sekretarz posiedzenia.

Dr Zachariasz Nowachowicz, delegat gminy Galicz [s] i przewodniczący. 
$[82 \mathrm{r}]$

\section{Sprawozdanie \\ z działalności Zarządu Gminy Karaimskiej w Wilnie, złożone walnemu zgromadzeniu w dniu 2 czerwca 1928 r.15}

Zarząd Gminy w okresie sprawozdawczym 1927-1928 r. oprócz zwykłej bieżącej roboty wykonał następujące zadania:

1) Brał czynny udział w przygotowaniu i w pracach konferencji gmin karaimskich w Haliczu w dn. 10-11 czerwca 1927 r.

2) Prezydium zarządu gminy na mocy uchwał konferencji w Haliczu interweniowało u władz w sprawie wyjednania ryczałtowych i stałych dotacji sum skarbowych na cele kulturalno-religijne całego społeczeństwa karaimskiego.

3) Zarząd gminy wspólnie z Duchownym Zarządem zorganizował i zwołał pierwszy ogólnopolski zjazd karaimski w Trokach, który odbył się w dniu 23 października $1927 \mathrm{r}$.

4) Prezes zarządu z polecenia zjazdu prowadził nadał pertraktacje z Jego Ekscelencją hachanem karaimskim oraz reprezentował nadal społeczeństwo karaimskie wspólnie z Duchownym Zarządem przed władzami do czasu przyjazdu J. E. do Polski.

5) Zarząd Gminy wspólnie z Duchownym Zarządem i przedstawicielami społeczeństwa karaimskiego miał zaszczyt witać Pana Prezydenta Rzeczypospolitej w Wilnie i w Trokach oraz Pana Wojewodę Raczkiewicza przy zwiedzaniu przez niego m. Trok i karaimskiej gminy w szczególności.

6) Zarząd Gminy organizował spotkanie J. E. na dworcu wileńskim oraz w kienesie wileńskiej.

7) Zarząd Gminy wyjednał u magistratu m. Wilna zarządzenia ułożenia chodnika na ulicy Grodzkiej do kienesy i poczynił kroki przed tymże magistratem, zmierzające ku wybrukowaniu tej że ulicy i otrzymaniu na własność działek ziemi zajętych pod świątynię i cmentarz karaimski.

8) Zarząd gminy wyjednał u kuratorium O. Sz. W. wyznaczenia nauczyciela religii karaimskiej.

/J. Łopatto/

15 LVMAB F 301-449, fol. 82 r. 
$[83 \mathrm{r}]$

\section{Protokół \\ obrad Walnego Zgromadzenia członków \\ Wileńskiej Karaimskiej Gminy Wyznaniowej z dnia 2 czerwca 1928 r. w lokalu Gminy przy ul. Grodzkiej 616}

Zebranie otwiera w obecności 93-ch członków gminy prezes zarządu pan mecenas Zajączkowski o godz. 20 m. 15. Na przewodniczącego zebrania większością głosów obrano pana I. Michajłowicza, na zastępców przewodniczącego powołano przez aklamację ponów A. Szyszmana i dra K. Łopatto, na sekretarza pana M. Kobeckiego.

Po przyjęciu do wiadomości porządku dziennego, składającego się z punktów: 1) sprawozdanie zarządu gminy za rok ubiegły: 2) wybory zarządu gminy: 3) kwestia nadania wileńskiej kienesie praw zboru parafialnego i zaprowadzenia osobnych ksiąg metrycznych dla gminy wileńskiej: 5) wolne wnioski, odczytano i przyjęto protokół poprzedniego zebrania z dn. 3 maja $1928 \mathrm{r}$.

Sprawozdanie zarządu złożył prezes pan mec. Zajączkowski, rozszerzając w przemówieniu zasadnicze punkty sprawozdania załączonego do niniejszego protokołu. Wobec tego, że pełnomocnictwa zarządu już wyczerpały się, prezes w imieniu własnym oraz kolegów składa dymisje. Na wniosek przewodniczącego pana Michajłowicza zebranie wyraża gorące podziękowanie ustępującemu zarządowi.

Wybory zarządu. Na wniosek pana mec. Zajączkowskiego ustala się liczbę obieralnych członków zarządu w ilości 6 osób przy 2 kandydatach. Po długiej dyskusji dotyczącej technicznej strony wyborów przystąpiono do głosowania. Zebranie wysuwa następujących kandydatów: Iz. Zajączkowski, Józef Łopatto, Izaak Michajłowicz, Ksenia Abkowiczówna, Izaak Rojecki, Tymfowicz, Zofia Kobecka, A. Szyszman, O. Pilecki i E. Aronowicz, którzy udzielili zgody na pracę w Zarządzie. Do komisji wyborczej prezydium powołało p.p. Zenaidę Łopattównę, Lidię Szolównę, R. Kobeckiego i A. Rojeckiego. Zarządzono 10-minutową przerwę celem wypełnienia kartek. Po wznowieniu obrad ogłoszono wyniki wyborów, w/g których na członków Zarządu zostali obrani pp. Iz. Zajączkowski, Józef Łopatto, Ksenia Abkowiczówna, Iz. Michajłowicz, Ab. Szyszman i Isaj Rojecki oraz na kandydatów p. p. Z. Tymfowicz i Zofia Kobecka.

Do punktu 3-go porządku dziennego w imieniu zarządu referował [83 v] pan mec. Zajączkowski, którego wniosek jednomyślnie przyjęto: „Walne Zgromadzenie członków Wileńskiej Karaimskiej Gminy Wyznaniowej prosi Jego Exelencję Hachana Karaimskiego o nadanie Kienesie Wileńskiej praw zboru parafialnego wraz z prawem prowadzenia ksiąg stanu cywilnego. Podczas dyskusji nad kwestią obsadzenia stanowiska p.o. hazzana w Wilnie większość mówców wypowiedziało

16 LVMAB F 301-449, fol. 83r-84r. 
się za wyborami nie pełniącego obowiązki tylko hazzana. Zgromadzenie zaakceptowało powyższą propozycję szeregu mówców, przyjmując większością głosów przeciw 17-tu przy jednym powstrzymującym się następujący wniosek: „Walne Zebranie przechodzi do ustalenia wysokości uposażenia hazzana oraz wyborów tegoż”. Na wniosek zarządu ustępującego jednomyślnie uchwalono ustalić od dnia 1 czerwca 1928 r. wysokość uposażenia miesięcznego dla hazzana w Wilnie w sumie 100 zł. z jednoczesnym upoważnieniem zarządu gminy do powiększenia tego uposażenia zależnie od okoliczności.

Wybory hazzana. Wystawiono dwie kandydatury: pana Józefa Łobanosa i pana Rafała Abkowicza. Na wniosek pana El. Jutkiewicza 47 głosami przeciw 40-tu uchwalono przystąpić do omawiania kandydatur. Prezydium otwiera listę mówców, zamykając ją przed udzieleniem głosu pierwszemu z mówców. Przemawiali panowie E. Jutkiewicz, Łopatto, Sz. Nowicki, St. Kapłanowski, Dubiński, Iz. Zajączkowski i powtórnie, jako wystawiający kandydatury panowie Łopatto i El. Jutkiewicz. Podczas długiej dyskusji, przerywanej przywoływaniem zgromadzonych i mówców do porządku, udzielono pierwszego ostrzeżenia ze wpisaniem do protokołu panu M. Łopatto za nieparlamentarne wyrazy, skierowane pod adresem kandydata pana Łobanosa. Po wyczerpaniu listy mówców przystąpiono do głosowania. Po przerwie komisja wyborcza w składzie podanym wyżej przystąpiła do odbierania kartek. W trakcie wyborów grupa obecnych na czele z panem Łopatto wysunęła wniosek o unieważnienie wyborów z powodu nieprawidłowego składania kartek. Na mocy uchwały prezydium po przerwie ogłoszono nowe wybory.

Wyniki głosowania dały: białe kartki 2.

$\mathrm{Na}$ kandydaturę pana Łobanosa padły 43 głosy.

Na kandydaturę pana Abkowicza 35 głosów.

Przewodniczący ogłosił wyniki, wg których na hazzana w Wilnie obrany został pan Łobanos.

W wolnych wnioskach zgromadzenie obrało przez aklamację komisję [84 r] rewizyjną w składzie panów Kozyrowicza, O. Pileckiego i E. Aronowicza.

O godz. 12 m. 37 w nocy obrady zamknięto.

Przewodniczący J. Michaiłowicz.

Zastępcy przewodniczącego dr Łopatto.

Sekretarz Michał Kobecki. 
